\title{
Aterotrombóza: antikoagulační léčba a perkutánní koronární intervence
}

\author{
Ivo Varvařovský \\ Kardio-Troll, Pracoviště invazivní kardiologie, Krajská nemocnice, Pardubice, Česká republika
}

Adresa: MUDr. Ivo Varvařovský, Ph.D., Kardio-Troll, Kyjevská 44, 53203 Pardubice, Česká republika, e-mail: ivovarvarovsky@kardio-troll.cz

\section{Úvod}

Krevní destička je v rozvoji arteriální trombózy dominujícím činitelem. Systému koagulační kaskády je připisována druhotná úloha. Přidání antikoagulační léčby k léčbě antiagregační přináší přesto další významné snížení rizika úmrtí a ischemických komplikací akutních koronárních syndromů. Antikoagulační léčba však zároveň zvyšuje riziko krvácivých komplikací a může tímto způsobem nepříznivě ovlivnit celkový výsledek léčby. Nové antikoagulační léky přinášejí cílenější účinek nebo zasahují na vyšších stupních amplifikačního systému koagulační kaskády. Nová antikoagulancia nepřinášejí zpravidla další snížení ischemických komplikací; jejich použití je však spojeno s menším rizikem krvácení, čímž vykazují lepší poměr přínosu a rizika. Použití antikoagulačních léčiv je vždy nutno hodnotit ve vztahu k intervenční léčbě akutního koronárního syndromu. Perkutánní koronární intervence (PCI) může totiž svou invazivní povahou zvyšovat riziko krvácení; na druhé straně ošetřením místa původu koronární nestability může anulovat přínos antikoagulační léčby.

\section{Antikoagulační léčba před perkutánní koronární intervencí}

Nefrakcionovaný heparin (UFH) přidaný k léčbě kyselinou acetylsalicylovou snižuje významně o jednu třetinu riziko úmrtí a infarktu myokardu při akutním koronárním syndromu. Optimální intenzita léčby UFH je při hodnocení pomocí testu aPTT 50-70 sekund (1,5-2,5násobek kontroly); zvyšování intenzity léčby vede k nárůstu krvácivých komplikací bez dalšího léčebného prospěchu. Po ukončení léčby UFH opět narůstá výskyt koronárních příhod a bez následné revaskularizace není dlouhodobý výsledek této léčby lepší než léčba samotnou kyselinou acetylsalicylovou. Jednoznačnými výhodami nefrakcionovaného heparinu je jeho krátký biologický poločas, snadná návaznost na PCI, možnost ověření aktuální úrovně intenzity léčby podle testu ACT a nízká cena léčby.

Nízkomolekulární hepariny (LMWH) jsou nejen farmakologicky heterogenní skupinou, ale liší se i z hlediska prokazatelnosti své klinické účinnosti. V léčbě akutního koronárního syndromu (AKS) neprokázal ve srovnání s UFH žádnou výhodu dalteparin (studie FRIC), ani nadroparin (studie FRAX.I.S.). Tinzaparin potom v př́mém srovnání s enoxaparinem ukázal menší klinickou účinnost (studie EVET). Enoxaparin tak zůstal díky studiím TIMI $11 \mathrm{~B}$ a ESSENCE jediným nízkomolekulárním heparinem $s$ prokazatelně větší klinickou účinností v léčbě AKS, než jakou vykazuje nefrakcionovaný heparin (pro úmrtí a infarkt myokardu RR =0,82, 95\% CI 0,69-0,97). Bezpečnost této léčby byla přijatelná. Při srovnatelném riziku vážného krvácení byl při léčbě enoxaparinem pouze vyšší výskyt nezávažných krvácení. Studie TIMI 11B a ESSENCE však používaly strategii časně konzervativní. Modernější studie, které zařadily PCI do léčebného programu časně a v dominantním rozsahu, přínos enoxaparinu ve srovnání s UFH již neprokazují (A-to-Z časně invazivní, SYNERGY). Americký projekt CRUSADE potom ukazuje, že hranice 48 hodin od zahájení antikoagulační léčby do PCI bude asi zlomovou pro prokázání přínosu enoxaparinu. Pokud byl nemocný léčen PCI do 48 hodin, bylo riziko ischemických i krvácivých komplikací zcela srovnatelné. Teprve antikoagulační léčba delší než 48 hodin vedla při použití enoxaparinu k menšímu výskytu ischemických i krvácivých komplikací.

Fondaparinux je prvním klinicky použitelným nepřímým inhibitorem faktoru Xa. Podobně jako hepariny potřebuje ke svému účinku molekulu antitrombinu III. Na rozdíl od heparinů však nevytváří komplexy s bílkovinami krevní plazmy, proto není v podmínkách AKS neutralizován, ani nevede $\mathrm{k}$ riziku heparinem indukované trombocytopenie. Jeho dobrá biologická dostupnost vede k potřebě podávání pouze jednou denně bez nutnosti monitorování účinku. 
Nevýhodou je nemožnost rychlého ověření aktuální účinnosti léčby pomocí testu ACT (aktivovaný koagulační test). V klinických studiích OASIS-5 (NSTEMI) a OASIS-6 (STEMI) byla přesvědčivě prokázána jeho srovnatelná účinnost $s$ hepariny při významně vyšší bezpečnosti léčby. Pravděpodobnost vážného krvácení se při agresivní léčbě enoxaparinem zvyšovala od 3. dne; v 9. dnu léčby již byla dvojnásobná. Tato skutečnost potom vedla k významnému zvýšení mortality v dlouhodobém sledování.

Př́mé inhibitory trombinu (DTI) mají ve srovnání s hepariny řadu výhod. Nepotřebují ke svému účinku antitrombin III, nevykazují významné interakce s proteiny akutní fáze a dokážou navíc pronikat i do již vytvořeného trombu. DTI snižují riziko úmrtí a infarktu myokardu, avšak (s výjimkou bivalirudinu) za cenu vyššího rizika krvácení. Pokud není léčba akutního koronárního syndromu do 3. dne doplněna koronární revaskularizací, léčebný účinek DTI se postupně vytrácí. Skupina DTI je z hlediska farmakodynamiky i farmakokinetiky velmi heterogenní, nejvíce prozkoumaným lékem $\mathrm{v}$ podmínkách současné léčby AKS je bivalirudin.

Př́mé inhibitory faktoru $\mathrm{Xa}$ jsou velmi nadějnou lékovou skupinou pro léčbu AKS díky dobrému poměru účinnosti a bezpečnosti. Intenzita léčby je snadno měřitelná běžně používanými testy (ACT, aPTT, INR). V současnosti jsou injekční i perorální formy léčiv hodnoceny v 1.-3. fázi klinických studií.

\section{Antikoagulační léčba během PCl}

Nefrakcionovaný heparin je podáván empiricky od prvního provedení koronární angioplastiky v roce 1977. Zpočátku byly dávky UFH velmi vysoké a odrážely zkušenosti kardiochirurgů s prevencí trombózy při vedení mimotělního oběhu. Se zavedením protidestičkové léčby a s narůstáním její intenzity postupně dávka UFH klesala. V současnosti je doporučováno podávání UFH na počátku PCI tak, aby hodnota ACT (hodnocená přístrojem Hemochron) dosahovala 250-350 s; v prŕípadě současné léčby inhibitory GP IIb/IIIa 200-250 s.

Nízkomolekulární heparin byl během PCI testován na základě teoretického předpokladu, že absence dlouhých heparinových řetězců povede k menší aktivaci trombocytů, a tím napomůže příznivějšímu průběhu intervence. Enoxaparin v dávce $0,5 \mathrm{mg} / \mathrm{kg}$ nitrožilně (i.v.) zajistí terapeutickou úroveň aktivity anti-Xa $0,5-1,0 \mathrm{IU} / \mathrm{ml}$ po dobu 2,7 hodiny, a zdá se tak z farmakologického hlediska optimálním režimem. Z hlediska klinického je však podávání enoxaparinu u stabilních nemocných při PCI ekvivalentní obvyklé léčbě nefrakcionovaným heparinem (studie STEEPLE). Při léčbě nestabilních nemocných časně invazivní strategií je účinnost enoxaparinu a UFH rovněž zcela srovnatelná (SYNERGY, A-to-Z), avšak bezpečnost léčby je horší při použití enoxaparinu. Proto v prŕípadě plánování časně invazivního postupu je dnes doporučováno použití UFH.

Fondaparinux má nejpříznivější bezpečnostní profil pro vedení dlouhodobé antikoagulační léčby AKS. Pokud tedy není PCI dostupná do 48 hodin, měl by být lékem první volby. Pro samotné zajištění PCI je však lékem nedostatečným, přinejmenším v dávce 2,5 mg denně. Ve studii OASIS-5 byla $\mathrm{v}$ tomto režimu pozorována významně častěji potenciálně nebezpečná komplikace - trombóza katetru. Provedení koronární angioplastiky má tedy být při léčbě fondaparinuxem doplněno vždy podáním UFH $\mathrm{v}$ dávce 50-100 IU/kg hmotnosti nemocného tak, aby bylo dosaženo obvyklých cílových hodnot ACT.

Bivalirudin je nejlépe prostudovaným lékem ze skupiny DTI v indikaci antikoagulačního zajištění PCI. Léčba se ukázala srovnatelně účinná i bezpečná jako léčba UFH (REPLACE-1), ale srovnatelně účinná a bezpečnější, pokud léčbu UFH rozšíríme o inhibitory GP IIb/IIIa (REPLACE-2). Monoterapie bivalirudinem je potom při PCI srovnatelně účinná jako režimy bivalirudin + inhibitor GP IIb/IIIa nebo UFH + inhibitor GP IIb/IIIa, avšak pouze za předpokladu předléčení clopidogrelem (studie ACUITY). Pokud nemocný není clopidogrelem předléčen, je vyšší bezpečnost monoterapie ztracena nižší účinností léčby. Snížení krvácivých komplikací PCI při léčbě bivalirudinem se navíc vůbec neodrazí ve snížení dlouhodobé mortality. Léčba bivalirudinem je dnes plně oprávněna $\mathrm{v}$ př́padě heparinem indukované trombocytopenie, jejímu rozšiřrení do běžné praxe brání výrazně vyšší cena ve srovnání s nefrakcionovaným heparinem.

\section{Antikoagulační léčba po perkutánní koronární intervenci}

Po provedení koronární revaskularizace není indikováno pokračování v antikoagulační léčbě, pokud k němu není jiná klinická indikace. Antikoagulační léčba po PCI nesníží riziko ischemických komplikací, pouze významně zvyšuje riziko krvácení.

\section{Závěr}

Antikoagulační léčba je nezbytnou součástí iniciální léčby akutních koronárních syndromů a používá se i pro zajištění intervenční léčby těchto nemocných. V hodnocení používaných léčebných postupů se jednoznačně prosazuje hledisko čistého klinického prrínosu léčby, sčítající hledisko účinnosti a bezpečnosti. Časné zařazení koronární angioplastiky do léčby nemocných (do 48-72 hodin) zvyšuje bezpečnost antikoagulační léčby a do značné míry smazává rozdíly v bezpečnostním profilu jednotlivých léčiv. Pokud je doba do provedení PCI delší, měly by být preferovány léky s menším rizikem krvácení.

\section{Literatura}

1. The Task Force for the Diagnosis and Treatment of Non-ST-Segment Elevation Acute Coronary Syndromes of the ESC. Guidelines for the diagnosis and treatment of non-ST-segment elevation acute coronary syndromes. Eur Heart J 2007;28:1598-660.

2. The Task Force for $\mathrm{PCl}$ of the ESC. Guidelines for percutaneous coronary interventions. Eur Heart J 2005;26:804-47.

3. Harrington RA, Decker RC, Cannon CP. Antithrombotic therapy for non-ST-segment elevation acute coronary syndromes. Chest 2008;133 (Suppl 6):670S-707S. 